\title{
Effects of Nitrogen Fertilization and Grass Species on Soil Physical Condition in Some Tropical Pastures ${ }^{1}$
}

\section{José Vicente-Chandler and Servando Silva ${ }^{2}$ \\ INTRODUCTION}

Soil compaction by livestock may become a serious problem in some soils as stocking rates are increased by heavy fertilization and pasture management is intensified. In the studies described in this paper, for instance, 2 to 3 head were carried per acre the year around. Yet, there are few quantitative data on changes caused in the physical condition of pasture soils by grazing animals. The authors have found no quantitative evaluation of nitrogen fertilization or forage species on soil compaction by grazing animals.

Keen and Cashen $(6)^{3}$ found that soil penetrability to a pointed rod decreased by trampling while Edmond ( 8 ) reported that soil-moisture content was decreased by trampling. Lieth (7) found that pore volume increased with decreasing trampling. Tanner and Mamoril (8) showed that many pasture soils suffer compaction by animal traffic which may decrease yields, while Heinonen (4) found that dense vegetation prevented excessive compaction in pastures.

The purpose of the present study was to measure: 1 , The effect of nitrogen fertilization rates applied to Napier, Guinea, Pangola, and Para grasses on soil physical condition in small grazed plots on Catalina clay in the humid mountains of Puerto Rico; and, 2, the effect of the first three grasses on soil physical condition in heavily fertilized, intensively managed pastures on both this soil and on irrigated Santa Isabel silty clay loam on the semiarid south coast.

\section{MATERIALS AND METHODS}

\section{SMALL-PLOT EXPERIMENT}

The plots of the experiments reported by Caro, Vicente, and Figarella (2) were used in the present study. The main plots were used to compare the effects of cutting versus grazing management. These were split into

1 This work was carried out cooperatively between the U. S. Department of Agriculture and the Agricultural Experiment Station of the University of Puerto Rico.

2 Project Supervisor, and Physical Science Technician (General) respectively, Soil and Water Conservation Research Division, Agricultural Research Service, USDA.

${ }^{3}$ Italic numbers in parentheses refer to Literature Cited, p. 86. 
plots of Napier, Guinea, Para, and Pangola grasses, which, in turn, were split into 10- x 20-foot plots receiving nitrogen at rates varying from 0 to 800 pounds per acre yearly. All treatments were replicated four times.

The experiment was carried out at Orocovis, which has a mean annual temperature of about $75^{\circ} \mathrm{F}$., with a seasonal variation of less than $10^{\circ} \mathrm{F}$. Annual rainfall averaged about 83 inches. The surface 6 inches of this Catalina clay, a deep, red lathosol on 30-percent slopes, had 4.5 percent of organic matter; a pH of 5.3; 16.5 m.e. of exchange capacity; and 10.4 m.e. of exchangeable bases per $100 \mathrm{gm}$. of soil.

The soil was limed to about $\mathrm{pH} 6.5$ and blanket additions of phosphorus and potassium were made at the rate of 200 pounds of $\mathrm{P}_{2} \mathrm{O}_{5}$ from 20-percent superphosphate per acre in one annual application, and 400 pounds of $\mathrm{K}_{2} \mathrm{O}$ from $\mathrm{KCl}$ per acre yearly in nine equal applications. Nitrogen was applied as ammonium sulfate in nine equal applications yearly.

The plots that had been grazed by livestock at 40-day intervals for $21 / 2$ years were sampled. Three undisturbed 3- $x$ 3-inch soil cores were taken with a Bradfield sampler at 0-3- and 3-6-inch depths in all plots of the grasses receiving 0 and 800 pounds of nitrogen per acre yearly.

\section{LARGE-SCALE GRAZING EXPERIMENTS}

Adjacent, heavily fertilized (500 pounds of 14-4-10 fertilizer applied per acre every 2 months), intensively managed 1-acre experimental pastures of Napier, Guinea, and Pangola grasses, also on Catalina clay, and which had been grazed for 18 consecutive months with $2 \frac{1}{2}$ head per acre, were also studied. Eight cores were taken at 0-3- and at 3-6-inch depths in plots of each grass.

Similarly fertilized, intensively managed, 1-acre experimental pastures of these three grasses on level, Santa Isabel silty clay loam, that had been grazed for 18 consecutive months at the rate of 3 head per acre, were also sampled. Rainfall averaged only about 35 inches yearly and was supplemented by frequent irrigation. This soil had a $\mathrm{pH}$ of $7.5 ; 2.1$ percent of organic matter; and an exchange capacity of 37.5 m.e. per $100 \mathrm{gm}$. of soil saturated with bases. Four cores were taken at 0-3- and at 3-6-inch depths in pastures of each grass.

\section{SOIL ANALYSIS}

The soil cores were weighed and then slowly saturated with water in a vacuum for several days. Percolation rates were determined by recording the rate at which water moved through the cores at a known head. Volume of large, quickly drained pores was determined by placing the soil cores in a Buckner funnel, setting a $60-\mathrm{cm}$. tension, and measuring the water removed after 15 minutes. The water removed at $60-\mathrm{cm}$. tension was meas- 
ured by bringing the cores to equilibrium with this tension and determining their loss in weight. Water retained at $1 / 2$ and 15 atmospheres of pressure was determined using pressure plates. Available water was taken to be that retained between $1 / 2$ and 15 atmospheres of pressure. The cores were finally dried in the oven at $110^{\circ} \mathrm{C}$., and bulk density was calculated by dividing their dry weight by the original volume. The pore space was calculated using a specific gravity of 2.65 as determined for this soil by VicenteChandler, et al. (9).

There was essentially no swelling of the cores while being saturated with water in the laboratory and, therefore, errors caused by this phenomenon were largely avoided. The fact that average maximum saturation values for the cores of Catalina clay, 62.3 percent, were almost identical with the calculated pore-space values, 62.5 percent, shows how little swelling occurred.

It is important to note that in all experiments the land was plowed repeatedly to a depth of 8 inches before the grasses were planted, presumably making this layer homogenous, and that the samples were taken 3 days after prolonged drenching rains when the soil was presumably at field capacity.

The volume of large pores is considered the best estimate of soil compaction with percolation rates and bulk densities as supporting evidence.

\section{RESULTS AND DISCUSSION}

\section{EFFECT OF TRAMPLING ON SURFACE SOIL}

A comparison of values for the 0-3- and the 3-6-inch depths in table 1 and figure 1 shows that, in the upper layer, volume of quickly drained pores was 42-percent less, volume of pores drained at $60-\mathrm{cm}$. tension 31-percent less, and percolation rates only about one-fourth as high as in the lower layer. Bulk density also averaged higher in the upper layer.

The data in table 1 show that compaction was largely confined to the upper 3 inches of soil, since values for the 3-6-inch layer under heavily fertilized Pangola grass harvested by cutting, which can be considered representative of untrampled soil, are similar to those for the 3-6-inch layer of the grazed plots. Therefore, a fairly accurate measure of soil compaction by grazing animals under these conditions can be obtained by comparing physical data for the upper and the 3-6-inch layers, particularly since the soil was initially well mixed by plowing.

Table 2 shows that trampling by grazing animals also generally caused some compaction of the upper 3 inches of soil in the large, intensively managed pastures on both soil types. Under all three grasses on Santa Isabel soil and with Guinea and Napier on Catalina, volume of pores 
TABLE 1.-The effect of grass species and nitrogen fertilization on soil physical condition at 2 depths under pastures of 4 grasses on Catalina clay after $21 / 2$ consecutive years of grazing 1

\begin{tabular}{|c|c|c|c|c|c|c|c|c|}
\hline $\begin{array}{c}\text { Grass species and N } \\
\text { applied per acre } \\
\text { yearly }\end{array}$ & $\begin{array}{c}\text { Bulk } \\
\text { density }\end{array}$ & $\begin{array}{l}\text { Saturated } \\
\text { percola- } \\
\text { tion rate }\end{array}$ & $\begin{array}{l}\text { Quickly } \\
\text { drained } \\
\text { pores }^{2}\end{array}$ & $\begin{array}{l}\text { Pores } \\
\text { drained } \\
\text { at } 60-\mathrm{cm} . \\
\text { tension }\end{array}$ & $\begin{array}{c}\text { Moisture } \\
\text { retained a } \\
\text { 1/2 at- } \\
\text { mosphere }\end{array}$ & $\begin{array}{l}\text { Moisture } \\
\text { retained'at } \\
15 \text { atmos- } \\
\text { pheres }\end{array}$ & $\begin{array}{l}\text { Available } \\
\text { water- } \\
\text { holding } \\
\text { capacity }\end{array}$ & $\begin{array}{c}\text { Actural } \\
\text { field } \\
\text { capacitys }\end{array}$ \\
\hline \multicolumn{9}{|c|}{$0^{\prime \prime}$ to $3^{\prime \prime}$ depth } \\
\hline & & $\begin{array}{l}\text { Inches } \\
\text { per hour }\end{array}$ & Percent! & Percent & Percent & Percent & Percent & Percent \\
\hline \multicolumn{9}{|l|}{ Pangola } \\
\hline $0 \mathrm{~N}$ & 1.02 & 3.1 & 3.7 & 6.5 & 48.9 & 35.9 & 13.0 & 53.3 \\
\hline $\begin{array}{l}800 \mathrm{lb} . \mathrm{N} \\
\text { Guinea }\end{array}$ & 1.03 & 10.4 & 4.9 & 9.0 & 48.7 & 35.6 & 13.1 & 51.1 \\
\hline $0 \mathrm{~N}$ & 1.02 & 6.1 & 4.7 & 7.5 & 44.9 & 34.0 & 10.9 & 51.8 \\
\hline $\begin{array}{l}800 \text { lb. } \mathbf{N} \\
\text { Para }\end{array}$ & 1.04 & 2.0 & 4.7 & 7.8 & 48.9 & 36.5 & 12.4 & 51.3 \\
\hline $0 \mathrm{~N}$ & 1.03 & 10.7 & 4.8 & 7.8 & 47.5 & 33.1 & 14.4 & 49.8 \\
\hline $\begin{array}{l}800 \text { lb. } \mathrm{N} \\
\text { Napier }\end{array}$ & .98 & 9.0 & 5.5 & 8.1 & 46.8 & 35.1 & 11.7 & 51.2 \\
\hline $0 \mathrm{~N}$ & .99 & 5.7 & 5.6 & 7.5 & 48.0 & 38.5 & 9.5 & 50.0 \\
\hline 800 lb. N & .94 & 12.4 & 7.1 & 9.2 & 45.8 & 36.4 & 9.4 & 50.5 \\
\hline Average & 1.01 & 7.4 & 5.1 & 8.0 & 47.4 & 35.6 & 11.8 & 51.0 \\
\hline
\end{tabular}

$8^{\prime \prime}$ to $6^{\prime \prime}$ depth

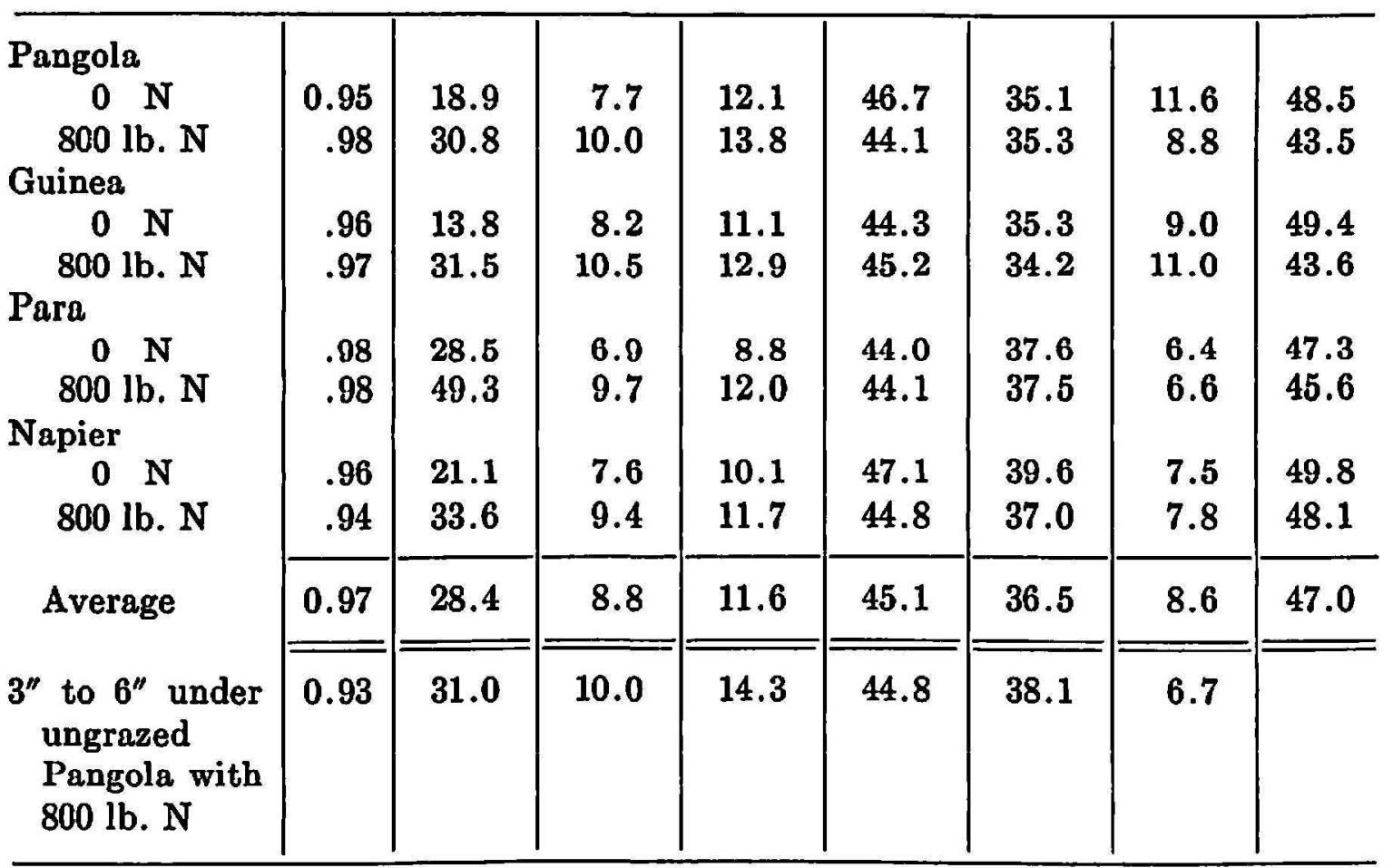

${ }^{2}$ All values are averages of 12 samples taken in 4 replicate plots with each treatment.

2 Pores drained after 15 minutes at tension of $60 \mathrm{~cm}$. of water.

3 Cores taken 3 days after drenching rains.

- All values for moisture are shown in percentage by volume. 


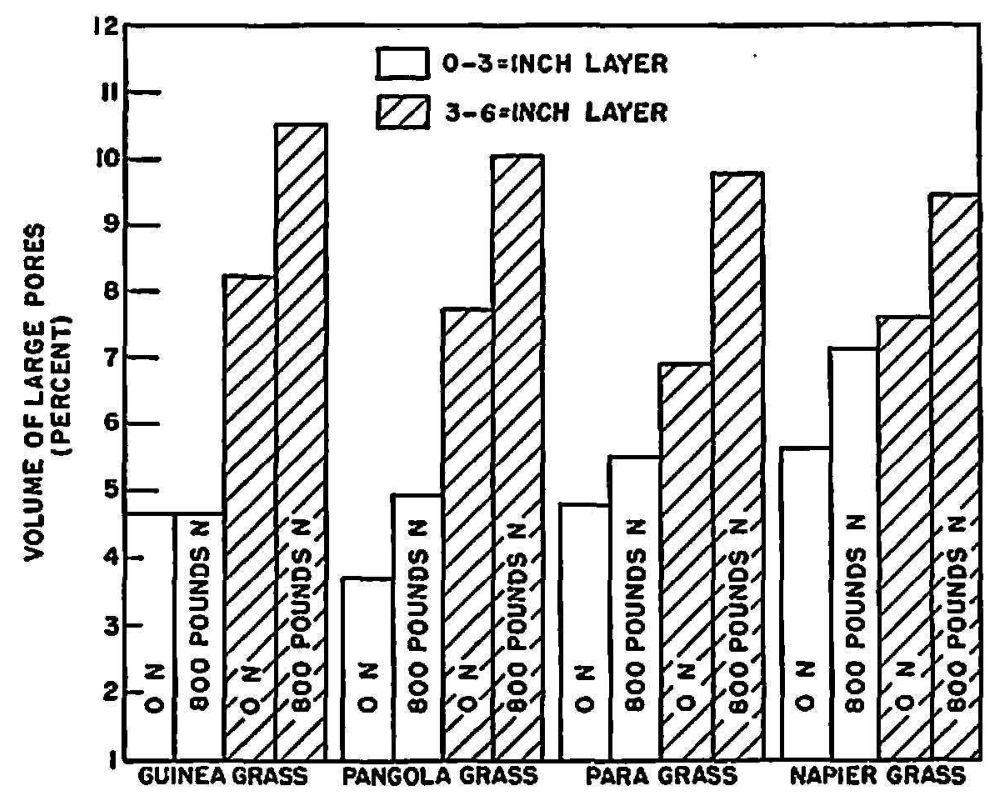

FIG. 1.-The effect of nitrogen fertilization of 4 grasses growing in Catalina clay on soil compaction by livestock over $2 \frac{1}{2}$ years, as evidenced by volume of large pores.

TABLE 2.-Physical condition at \& depths in 2 soils under heavily fertilized, intensively managed pastures of 3 grasses after 18 consecutive months of grazing 1

\begin{tabular}{l|c|c|c|c|c|c}
\hline \multirow{2}{*}{ Grass } & \multicolumn{2}{|c|}{ Bulk density at- } & \multicolumn{2}{|c|}{$\begin{array}{c}\text { Volume of pores drained at } \\
60-\mathrm{cm} \text {. tension at- }\end{array}$} & \multicolumn{2}{|c}{$\begin{array}{c}\text { Saturated percolation } \\
\text { rate at- }\end{array}$} \\
\cline { 2 - 3 } & $0^{\prime \prime \prime}-3^{\prime \prime}$ & $3^{\prime \prime}-6^{\prime \prime}$ & $0^{\prime \prime}-3^{\prime \prime}$ & $3^{\prime \prime}-6^{\prime \prime}$ & $0^{\prime \prime}-3^{\prime \prime}$ & $3^{\prime \prime}-6^{\prime \prime}$ \\
\hline
\end{tabular}

Santa Isabel silty clay loam

\begin{tabular}{l|l|l|l|l|l|l}
\hline Pangola & 1.36 & 1.33 & 8.1 & 11.8 & - & - \\
Guinea & 1.43 & 1.25 & 8.5 & 15.6 & - & - \\
Napier & 1.40 & 1.31 & 9.5 & 12.6 & - & - \\
\hline
\end{tabular}

1 Values for Catalina soil are averages of 8 replicates, those for Santa Isabel of 4 replicates.

drained at $60-\mathrm{cm}$. tension was significantly less in the upper 3 inches than in the second 3. Percolation rates were also significantly lower in the upper 3 inches of Catalina clay with all except Pangola grass. Bulk density of the upper 3 inches of soil was significantly higher under Guinea and Napier 
grasses on the Santa Isabel silty clay loam and under Guinea on the Catalina clay.

It is emphasized, however, that while grazing resulted in marked change in some of the measured physical properties, none of them fall within the range that would be considered unfavorable for crop production.

Table 3 shows that the limited compaction caused by trampling did not decrease forage yields. The plots of Guinea, Napier, and Pangola grasses grazed throughout the course of the experiment actually produced higher residual yields than those harvested by simulated grazing and hence essentially untrampled.

TABLE 3.-Yields of the 4 grasses produced over a residual 60-day period by the plots actually grazed by livestock during the small-plot experiment and by those with simulated grazing and hence essentially untrampled

\begin{tabular}{l|c|c}
\hline \multirow{2}{*}{ Grasses } & \multicolumn{2}{|c}{ Pounds of dry forage per acre } \\
\cline { 2 - 3 } & Grazed & Ungrazed \\
\hline Para & 5,000 & 5,600 \\
Guinea & 5,600 & 4,800 \\
Napier & 6,300 & 5,500 \\
Pangola & 6,900 & 6,200 \\
\hline
\end{tabular}

\section{EFFECT OF SOIL COMPACTION ON AVAILABLE WATER}

Table 1 shows that the compacted upper layer of Catalina clay retained significantly more moisture at actual field capacity and at $1 / 2$ atmosphere and, since moisture retention at 15 atmospheres was not appreciably affected by compaction, had a significantly higher available water-holding capacity. Jamison (5) has also reported increases in available water-holding capacity with compaction.

Figure 2 shows that as the volume of large pores were decreased by compaction, the available water-holding capacity of Catalina clay increased markedly, as did the actual field capacity also. For example, by decreasing the volume of large pores from 12 to 8 percent, the available water-holding capacity was more than doubled from about 6.5 to 14 percent. This means that about 0.22 inch more water could be stored for plant use in the upper 3 inches of soil. This may favor plant growth on this very porous soil which retains a high percolation rate and desirable proportions of large pores for aeration when compaction is moderate as it is under heavily fertilized grasses. 


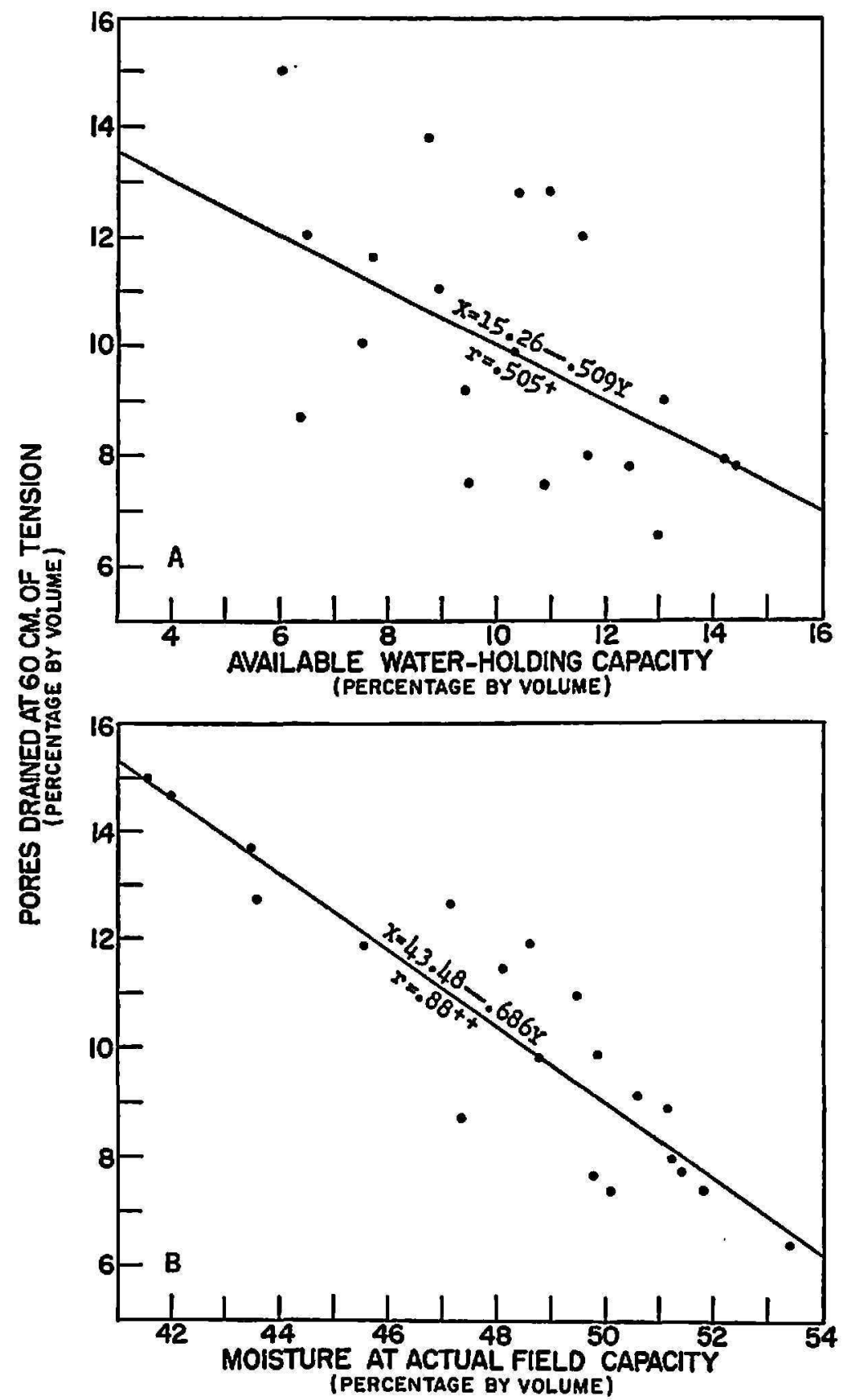

Frg. 2.-Relationship between pores drained at $60 \mathrm{~cm}$. of tension and available water-holding capacity (A) and actual feld capacity (B) in a Catalina clay soil.

EFFECT OF NITROgeN FERTILIZATION ON SOIL PHYSICAL CONDITION

Nitrogen fertilization of the grasses reduced compaction of the surface of Catalina clay under all grasses except Guinea (table 1 and fig. 1). The application of 800 pounds of nitrogen per acre yearly resulted in the following differences in the upper 3 inches of soil: 1 , A significant increase in the volume of quickly drained pores with Para, Pangola, and Napier grasses; 2 , a significant increase in the volume of soil pores drained at $60-\mathrm{cm}$. tension 
with Pangola and Napier grasses; 3 , a marked increase in percolation rates with Pangola and Napier grasses, and 4, a significantly lower bulk density under Para and Napier grasses. The reduction in surface-soil compaction due to heavy nitrogen applications may be explained by greater vegetative cover and root development accompanying the tremendous increases in forage yields reported by Caro, Vicente, and Figarella (2).

That nitrogen fertilization did not affect surface-soil condition under Guinea grass, although forage yields were increased tremendously, is explained by the fact that this grass grows in clumps with bare soil between, where the soil cores were perforce taken.

The effect of nitrogen fertilization on soil physical condition was even more marked in the 3-6-inch layer of Catalina clay as shown in table 1. The application of 800 pounds of nitrogen per acre yearly sharply increased the volume of quickly drained pores (fig. 1) and of pores drained at $60-\mathrm{cm}$. tension, and the percolation rate with all four grasses. On the average, quickly drained pores were increased by about 30 percent; those drained at $60-\mathrm{cm}$. tension by about 20 percent; and percolation rates by about 80 percent. This effect of nitrogen fertilization can be attributed to increased root development.

\section{EFFECT OF GRASS SPECIES ON SOIL COMPACTION}

Although grass species with heavy fertilization had no marked over-all effect on soil condition in the small plots on Catalina clay (table 1 and fig. 1), the 3-6-inch layer of soil under Pangola grass had more pores drained at $60-\mathrm{cm}$. tension at both $\mathrm{N}$ levels than Napier or Para grasses.

There was apparently no surface-soil compaction under Pangola grass in the large pastures of Catalina clay. No significant difference in bulk density, percolation rates, or volume of large pores occurred between the upper and the 3-6-inch layer of this soil (table 2). The surface 3 inches of Santa Isabel silty clay loam under Pangola grass, however, had less volume of pores drained at $60 \mathrm{~cm}$. of tension than did the 3-6-inch layer, indicating some compaction.

On the other hand, some compaction of the surface soil by trampling occurred under Guinea and Napier grasses in both soils. Volume of pores drained at $60-\mathrm{cm}$. tension was significantly lower in the upper 3 inches of both soils with these grasses, as were percolation rates in the Catalina clay. The bulk density of the upper 3 inches of both soils under Guinea grass was also significantly increased by trampling.

The fact that better soil physical condition was apparently maintained under Pangola grass than under Guinea or Napier is easily explained. This grass forms a thick, dense sod covering the soil almost completely and trampling effects are distributed over the entire soil surface. Guinea grass, 
on the other hand, grows in large clumps with essentially bare soil between, since vegetation cannot thrive here where the soil is thoroughly permeated by the roots and densely shaded by the overhanging leaves of this grass. These bare areas account for about a third of the soil surface. Livestock avoid stepping on the clumps and traffic is concentrated on the bare soil between, accentuating compaction precisely where the soil cores must be taken. A similar condition, although somewhat attenuated, occurs with Napier grass, which also tends to grow in clumps.

Therefore, there may not be much difference in total soil physical condition on a given area under the various grasses, since the untrampled soil under the clumps of Guinea grass would compensate to some extent for the compacted bare areas between.

\section{SUMMARY}

The effect of intensive grazing on compaction of Catalina clay and of Santa Isabel silty clay loam as influenced by four grass species and the rate of nitrogen fertilization was determined.

Although both soils were compacted to some extent by grazing animals, the effect was not important and did not extend below the surface 3-inch layer.

Nitrogen fertilization reduced surface-soil compaction in Catalina clay under Pangola, Para, and Napier grasses, but not under Guinea grass, and resulted in increased percolation rates and volume of large pores in the 3-6-inch soil layer with all four grasses.

Surface-soil compaction by livestock was apparently less with Pangola grass than with Guinea or Napier. However, animal traffic is concentrated on the bare soil between clumps of the latter two grasses where the soil cores must be taken, and the untrampled surface under the clumps would have a compensating effect.

Soil compaction by trampling does not appear to be a serious problem with well-fertilized pastures on the typical latosols of Puerto Rico's mountains, even at high stocking rates and with clump grasses.

\section{RESUMEN}

Se estudia aquí el efecto del abonamiento con nitrógeno y de la especie de yerba sembrada sobre la condición física de un suelo Catalina arcilloso y Santa Isabel arcilloso lómico bajo pastoreo intenso.

Aunque ambos suelos se pusieron algo más compactos debido al pisoteo del ganado, este efecto no se extendió más allá de las 3 pulgadas superiores.

El abonamiento con nitrógeno disminuyó este efecto del pisoteo en el Catalina arcilloso con las yerbas Pangola, Para, y Napier, pero no con la yerba Guinea. El abonamiento con nitrógeno aumentó la infiltración de agua 
en este suelo, así como el volumen de poros de mayor tamaño con estas cuatro yerbas.

Aparentemente, se comprimió menos el suelo bajo la yerba Pangola que bajo de la Guinea o de la Napier. Sin embargo, con estas últimas, el pisoteo se concentró entre las macollas donde por necesidad se tomaron las muestras de suelo, teniendo el area sin pisotear bajo las macollas un efecto compensatorio.

La compactibilidad del suelo por el pisoteo del ganado tal parece no es un problema serio en los pastos bien abonados en suelos latosol típicos de las montañas de Puerto Rico, aún pastando mucho ganado por unidad de terreno y con yerbas de macollas.

\section{LITERATURE CITED}

1. Abruña, F., Pearson, R. W., and Elkins, C., Quantitative evaluation of soil reaction and base status changes resulting from field applications of residual acid nitrogen fertilizers, Soil Sci. Soc. Amer. Proc. 22 539-42, 1958.

2. Caro-Costas, R., Vicente-Chandler, J., and Figarella, J., The yield and composition of five tropical grasses as affected by season, nitrogen fertilization and harvest procedure, approved for publication in J. Agr. Univ. P.R., 44 (3).

3. Edmond, D. B., The influence of treading on pasture, a preliminary study, New Zealand J. Agr. Res. 1 319-28, 1958.

4. Heinonin, R., Soil Factors Affecting the Performance of Pasture Growth, Agrogeol. Julk, 61 pp. 1953.

5. Jamison, V. C., Changes in air-water relationships due to structural improvement of soils, Soil Sci. 76 (2) 143-52, 1953.

6. Keen, B. A., and Cashen, G. H., Studies in soil cultivation VI: The physical effect of sheep folding on soil, J. Agr. Sci. 22 126-34, 1932.

7. Lieth, H., Pore volume of grassland soils and its relationship to management and plant stand, Z. Acker-u-P Fe Bau 98 453-60, 1954.

8. Tanner, C. B., and Mamoril, C. P., Pasture soil compaction by animal traffic, Agron. J. 51 329-31, 1959.

9. Vicente-Chandler, J., Silva, S., and Figarella, J., Some limitations in the use of the air picnometer, J. Agr. Univ. P.R. 40 (3) 179-88, 1956. 